\title{
THE VALUE OF JULIUS CAESAR AS ETHNOGRAPHER*
}

\section{B.M. Bell, Rhodes University}

Caesar's campaigns in Gaul, Germany and Britain occasioned great excitement in Rome. For Catullus "the Gaulish Rhine, the formidable Britons, remotest of men" represented "the memorials of great Caesar" (Cat. 11.10-11). Cicero too considered Caesar's exploits against the Britons the stuff of poetry ( $Q$ Fr. 2.16.14). The reading public must have been interested in what he had to say about his foreign adversaries.

They had every reason to expect that ethnography would feature in the published Commentarii. The subject matter was essentially contemporary history. In bistorical writing going back to Herodotus it was customary to insert formal ethnographic digressions into the narrative. Alexander the Great had established a tradition of conducting full-scale studies of areas where he was engaged, and any Roman general with pretensions to greatness was bound to do likewise. It may also have been customary for governors or generals reporting back to the Senate to enliven their reports with descriptions of little-known peoples and places. As the Commentarii were based on such annual reports, readers may well have had a preview of what to expect, prior to publication.

From Caesar's own point of view ethnographical material had its uses. By $56 \mathrm{BC}$ he was having to justify his continued presence in Gaul. His subsequent invasion of Britain likewise required motivation. Descriptions of the ultimi Britanni could lend tangibility to them and immediacy to the threat they allegedly posed. The Romans had been obsessed with Gauls since they sacked Rome in 390 BC Interesting information about them might well convince politicians in Rome that Caesar's continued presence in the north west was justified. Selection of detail and the emphasis and presentation of the material offered opportunities for propagandistic exploitation, as we shall see in the case of the Germans.

Convention and personal interest then, compelled Caesar to turn his hand to ethnography, and it is the aim of this paper to assess his value as an ethnographer.

In his accounts of foreign enemies, Caesar's reading public may well have expected fresh insights gained from the author's personal experience. To what extent does Caesar's value as an ethnographer lie in accurate first hand observation?

Caesar was certainly in a position to obtain information about the peoples he was describing. He received reports from traders ( $B$ Gall. 1.39.1; 4.2.1; 3.3 (in Germany); 2.15.4 (in Gaul); 4.20.3-5 (Gallic traders with Britain)) and enemy captives, (B Gall. 1.50.4-5 (Germans); 2.4.1; 15.3-5; 16.1 (Gauls)) as well as his own scouts. He was in contact with Gauls, he had ample opportunity to consult men like Diviciacus for clarification or information, and may well have done so. He also conducted his own independent research into such scientific questions as the relative length of nights in Britain and on the continent (B Gall. 5.13.4).

When he comes to handle his material on foreigners Caesar treats it in two different ways. He enlivens and varies his narrative with information and incidental comment about the enemies he was facing. Ethnographic material is also formally set out in the type of

- I would like to express my appreciation to the journal's referee who provided useful suggestions and stimulating comments on an earlier version of this paper. 
extended excursus common in history, which has no direct connection to the narrative ( $B$ Gall. 4.1-3 on the Suebi; 5.12-14 on the Britons and 6.1.1-28 on the Gauls and Germans).1 Caesar's personal involvement in these two forms of exposition differs.

Personal experience informs his narrative. The frequency of phrases like suo more suggests that these details were added from his own observation ( $B$ Gall. 1.4.1; 2.13.3; 5.37.3; $56.2 ; 7.21 .1 ; 22.2 ; 33.3 ; 40.7 ; 48.3)^{2}$. Clearly his descriptions of Gallic methods of attacking a town (B Gall. 7.23), or their modes of settlement (B Gall. 6.30.3) derive from his own experience. He had learnt at first hand about German mixing of cavalry and infantry ( $B$ Gall. 1.48.5-7), their forming of a laager of wagons containing the womenfolk around their battleline, as a deterrent to flight ( $B$ Gall. 1.51.2-3), the ships of the Veneti (B Gall. 3.13), British chariots and fortified places ( $B$ Gall. 5.16; 21.3). Beyond the military sphere, his account of the institutions of the Aedui is meant to cast light on the politics of the Gallic situation as he saw it. The personal touch lends authenticity to his statements, and justifies Tacitus' view of Caesar as the summus auctorum in respect of his knowledge of Gaul (Germ. 28.1).

Yet it is noteworthy that personal observations are confined almost exclusively to the narrative sections ${ }^{3}$. When Caesar discusses the political, religious and social institutions of the Gauls in the ethnographic excursus ( $B$ Gall. 6.11-20) remarkably little bears the stamp of genuine first hand experience. The material was obviously selected because it interested Caesar (e.g. his description of Gallic methods of reckoning time, an interest reflected in his reform of the Roman calendar), and his treatment of the material betrays his Roman viewpoint 4 . But all the topics covered - tribal leadership, dependants, gods and religious practices, the upbringing of children, the status of wives, dowries, funerals, even the measurement of time are standard ethnographic themes5.

The same is true of the excursus on Britain. Here too the subjects discussed are traditional: the tribes which inhabit the country, the size of the population, their dwellings, economic livelihood and diet, appearance and family relationships, the shape and location of the island, its natural resources and climate. Similar themes recur in the formal discussions of the Suebi, and of German tribes in general.

The significance of this traditionalism needs to be assessed in terms of the literary conventions governing ethnography.

Every genre of ancient literature was circumscribed by convention, and ethnography was no exception. In the formal excursuses (the earliest in extant Latin literature) Caesar was working within a tradition whose principles had been established by Greek writers going all the way back to Hecataeus of Miletus and Herodotus 6 , and, for Caesar, culminating

1 The excursus on Britain and parts of the formal account of Germany were long considered later interpolations, but are now generally accepted as authentic, (see Rawson 1985:259). They are here taken to be so.

2 See Beckmann 1930:123-138 on evidence of personal observation.

$3 \quad B$ Gall. 5.13.4 is an exception.

4 See Müller 1980:69-71; Rawson 1985:260, 261.

5 See Trüdinger 1918: Index to topoi, and cf. the subjects treated in Tacitus' Germania.

6 Müller 1972:53-94 actually traces Greek ethnography all the way back to Homer and Hesiod, and discusses ethnographic material in the Presocratic philosophers. 
most recently in Posidonius. Tradition laid down the topics discussed7 and the kind of material included. Readers had certain expectations, and Caesar had to take these into account in making his own formal contributions to the genre. Not surprisingly, then, the subjects covered are traditional.

What is more, much of the material derives from literary sources. Caesar himself indicates that he was familiar with Eratosthenes and "certain Greeks" who wrote about the Hercynian forest (B Gall. 6.24.2) Scholars have spent much effort on Quellenforschung, in particular attempting to trace Caesar's material back to Posidonius 8 . Certain topics, like Gallic dependants and Druids, treated by Caesar recur in Greek ethnographic writers known to have used Posidonius (Diod. 5.29.2; 31.2ff. = Posidonius FGH 87 fr.116; Strab. 4.4.4 (197), $5(198))^{9}$, and Caesar's accounts may well come from the same source. This would not invalidate Caesar in the eyes of his contemporaries. It merely affirms that in those sections where his material may derive from literary sources he was again conforming to the literary principles governing ethnography. Posidonius, a writer on Celts who, like Caesar, had actually visited Gaul, had auctoritas and had to be taken into account in any subsequent ethnography of Gaul. In such matters Romans were conservative, imitating their models closely (as Strabo was later to complain about Roman writers on Spain (3 C 166)). Caesar could not afford to stray too far from familiar sources and the expectations they aroused. On Gaul Caesar may of course have corrected details in his sources 10 , but he seems to have felt that acknowledged personal observation was for the narrative where he was breaking new ground, rather than the tradition-bound ethnographic excursuses.

The value of particular portions of the formal ethnologiae has been called into question.

It has been pointed out, for instance, that Caesar's treatment of Gallic gods leads to misinterpretation. In naming Gallic and German divinities he employed what Tacitus later called interpretatio Romana (Germ. 43.4) - the identification of foreign deities with their nearest Roman equivalents. Germans consider gods those powers which they can see and which obviously benefit them - the Sun, Moon and "Vulcan" (B Gall. 6.21.2)11. Gauls worship "Mercury", "Apollo", "Mars", "Juppiter", "Minerva" and "Dis" (B Gall. 6.1718.1). Caesar's Celtic "Mercury", it is argued, was more likely an ancient agricultural or fertility god 12 , and it seems that the Celts did not actually attribute exclusive functions to their gods13. Yet such misrepresentation cannot be ascribed to Caesar's Roman chauvinism. Greek writers before him had identified foreign deities with their nearest Greek equivalents, so it was to be expected that Caesar, writing in Latin for a Roman audience, would employ interpretatio Romana when discussing Gallic and German divinities. This would be as natural as close adherence to Greek literary models.

7 On these topics see Schroeder 1921; Trïdinger 1918: Index to topoi.

8 Klotz 1910:120; Norden 1922:99f.; Momigliano 1975:67, 70-72.

9 On Posidonius' account of Gauls see Strasburger 1965:47.

10 In the case of Britain and Germany, due to limited personal contact, he was not in such a good position to do so. This is not to say that accurate information was not available. Even in the case of Britain, there had been Roman contact with the tribes living there for some time prior to Caesar's invasions. See Rice Holmes 1907:307-312.

11 This account is seriously incomplete and simplistic: Rawson 1985:261; Walser 1956:65.

12 Macculloch 1911:24f..

13 Chadwick 1971:143, 154f.. 
Then there is the notorious passage on the boundless Hercynian forest with its extraordinary fauna ( $B$ Gall. 6.25-28). Many scholars have regarded these chapters as a later interpolation. Some doubtless believe that Caesar was incapable of recording fabulous tales about deerlike oxen with a single horn between their ears, branching out at its extremity like a tree, or elks whose legs had no joints, so that when they fell they could not rise again. Caesar reports solemnly that they lean against trees when sleeping, enabling hunters to undermine the roots of their props - tree and elk collapsing together.

Again, such material was traditional and may well derive from Eratosthenes, who is mentioned by name in chapter 24 . One has only to compare Roman accounts of India - a remote and mysterious land reputedly inhabited by fabulous peoples - men with umbrella feet, men who jumped along on one leg like pogosticks, and others who sustained life on smells. India also boasted fabulous beasts like gold-digger ants, and animals and plants of immense size. Such stories derive from Hellenistic sources. In spite of the fact that accurate information about contemporary India must have been available from traders and other adventurers, Roman writers well into the Empire still unquestioningly reproduce these myths ${ }^{14}$. Such tales were expected in ethnography. Caesar, in including the elk and the auroch, was merely acting according to the conventions of the genre (and perhaps pandering to Roman fascination with the exotic).

The content of Caesar's formal ethnologiae, then, is entirely traditional. To assess their contribution we need to look, not so much at what he did in them, as at what he did not do.

Caesar may have incorporated fabulous tales, but he excludes myth per se. It was common in ethnography to refer to Graeco-Roman mythological figures associated with a region. Various Roman writers, for instance, mention the wanderings and triumphs of Hercules and Liber in India (Sen. Ep. 94.63; Curtius 3.10.5; 9.2.29;4.21; 8.5; 10.24; Pliny $H N$ $4.39 ; 16.144)^{15}$. Close in time to Caesar himself, Sallust, discussing the original inhabitants of Africa, reports the local belief that after the death of Hercules in Spain, Medes, Persians and Armenians from his disintegrating cosmopolitan army found their way to Africa and settled there (Iug. 18.2-5). In the case of Gaul such material was accessible to Caesar. Diodorus (5.21.2) records that Hercules founded Alesia, whose siege occupies so much of Caesar's Book 7. The ancestry of Gauls is traced back by Diodorus and Parthenius to the various sons of Heracles, and even to the nymph Galatea (Diod. 5.21.2; Parthenius 30). All this is eschewed by Caesar, lending a more scientific air to his accounts.

It has also been pointed out that Caesar places his main emphasis on the description of people rather than geography16. Ethnography and geography, as subjects, were not clearly defined in antiquity, and were commonly combined. It was not until Tacitus that the two were effectively separated17, but Caesar went some of the way towards this end.

14 Fabulous peoples: Pliny $H N$ 7.22ff. cf. Gell. $N A$ 9.4.9f.; Apul. Flor. 6; gold-digger ants: Mela 3.62; Pliny $H N 11.111 ; 33.66 ; 37.147$. On the great size of Indian animals see Mela 3.62; Pliny $H N 7.21$; 8.32; Curtius 8.12.11; 9.1.4; 3.12; 4.18; 8.1f.; Apul. Flor. 6. Virgil and Pliny comment on the large size of Indian trees (Verg. G. 2.122ff.; Pliny $H N 7.21$ ). Bamboo grew to such a size that single internodes could be made into boats (Mela 3.62; Pliny $H N 7.21 ; 16.162$ - a statement first made by Herodotus (3.98.3)). 
Geographical and anthropological topoi remain combined in the excursus on Britain, and the passage on the location and extent of the Hercynian forest belongs properly to the realm of geography. But the brief geography of Gaul, introduced by the now famous Gallia est omnis divisa in partis tres, which begins the Bellum Gallicum, is well separated from the ethnographic excursus in Book 6. Caesar also shows a tendency to provide geographical information where it is relevant to the narrative, effectively distinguishing it from comment on people. For instance, a digression on the source and course of the Rhine, and its tributary, the Meuse, follows the statement that the Germans had sent cavalry across the Meuse to bring back plunder and supplies (B Gall. 4.9-10).

However an interest in geography may not be Caesar's motive for inserting such pertinent information into the text. Topographical detail may serve an apologetic purpose. The account of the natural defences of Vesontio, for instance, vindicates Caesar's decision to anticipate Ariovistus' seizure of it, and do so himself ( $B$ Gall. 1.38). Caesar's apparently incidental mention of the natural and artificial defences of Cassivellaunus' stronghold leads to a rather dismissive definition of the British oppidum. His underlying intention however is not so much to provide geographic, or even ethno-geographic information, as to establish the fact that Cassivellaunus' particular oppidum represented an unexpected challenge. The ease with which it fell to Caesar appears the more commendable in consequence ( $B$ Gall. 5.21.2-5). But, whatever his motives, an effect of such passages was to incorporate geography into the narrative rather than to confine it to the ethnographic excursuses.

Ethnographers, particularly those with a Stoic bias, like Posidonius, who believed everything in the universe to be interrelated, conflated geography and ethnography by explaining national character in terms of climate and environment. Proximity to, or remoteness from the sun, for example, resulted in profound differences in the peoples who inhabited the southern and northern extremities of the world (Posidonius FGH 87, $121=$ Vitr. De Arch. 6.1). Caesar ignores such explanations of ethnic character and appearance, thereby further separating ethnography from geography.

Caesar was also the first to distinguish Germans and Celts ${ }^{18}$, and provide the first ethnography of Germans as a separate, identifiable race. This represents a deviation from the Posidonean tradition which had given more weight to the similarities between Celtic and German institutions (cf. Strab. 4.4 .2 (195f.); 7.1.2 (290)). Caesar's departure from tradition has been hailed as a contribution to ethnography. This may be, particularly from the point of view of German scholars. But before Caesar is given unreserved credit for this distinction, we need to examine his motives in differentiating so sharply between Gauls and Germans. His aim may not have been anthropological accuracy, but to grind his own axe.

Germans posed a problem for Caesar. In destroying Ariovistus he had taken the side of the Gauls against an officially friendly people and removed a recognized rex socius et amicus populi Romani. His actions needed to be vindicated. What is more, Caesar's military success against the Germans was limited. He did not reach the more distant tribes of Germany, and he may have felt concerned to justify the limits of his campaigns. These ulterior motives colour the German ethnographic excursus, and call into question its value.

It was necessary for Caesar's purpose to differentiate Gauls (deserving support) and Germans (unworthy friends of Rome). The Posidonean tradition which stressed similarities must be overturned. Accordingly, Caesar presents the Gallic and German excursuses side by side, boldly declaring his intention to set out quo differant hae nationes inter sese - $(B$ Gall. 6.11.1). The Gallic excursus follows. Gauls are viewed in Roman terms. Though 
some of their customs may be different, or even barbaric, their civilization is seen as analogous with Rome's19. Then follows Germani multum ab hac consuetudine differunt ( $B$ Gall. 6.21.1).

The Germans do not have Druids. This is the only specific difference mentioned, but the ensuing account fixes a great gulf, not only between Germans and Romans, but between Germans and the whole civilized world. Contrasts are implied in negative terms:- Germans have never heard of most of the Roman pantheon ( $B$ Gall. 6.21.2 cf. 17-18.1), they do not practise agriculture and no individual owns land ( $B$ Gall. $6.22 .1-2)$, they have no common government ( $B$ Gall. 6.23.5), looting and violating the rights of hospitality are no crime ( $B$ Gall. $6.23 .6,9)$. They are presented as indigent, their tribal institutions specifically designed to prevent the amassing of wealth ( $B$ Gall. $6.22 .4 ; 24.4$ ) - hardly worth the trouble of conquering perhaps? Although Caesar must have been aware that tribes on the right bank of the Rhine at least, had permanent oppida, his Germans (except for the Celticinfluenced Volcae Tectosages) are nomads living in temporary shelters in the midst of vast wildernesses ( $B$ Gall. 6.22.3). This picture may be traditional: it occurs too in Strabo (4.4.2 (196); 7.1.3-4 (291)), but Caesar may well have chosen to reproduce these particular details for his own purposes. The implication perhaps is that Germans are impossible to pin down and not worth pursuing, like Scyths and other nomadic barbarians.

Caesar is also concerned to highlight the warlike and savage nature of these intractable enemies. Germans' whole life is devoted to hunting and military pursuits (B Gall. 6.21.4 cf. 1.39.1), and even their political institutions are designed to maintain their studium belli gerendi ( $B$ Gall. 6.22.2-3). They are superior in strength even to Gauls ( $B$ Gall. 6.24.1). Like the wild and barbaric people they are, they wander about half-naked or clad in skins, the hallmark of primitive man ( $B$ Goll. 6.21.5)20. This was not the whole story. Germans may ordinarily have worn the renones, or waterproof skin cloaks21 Caesar and other authors mention, (B Gall. 6.21 .5 cf. Sal. Hist. 3 fr. 104 (Maurenbrecher); Serv. G. 3.383), but burial finds indicate that the more affluent at least, used textiles and understood weaving, as Caesar must have seen for himself.

But Caesar was not particularly concerned with providing an accurate scientific account of foreign mores. His tone may appear detached, but he was selecting traditional details which would enhance the importance of his limited campaigns and play upon Roman prejudices about the barbarians who threatened their frontiers22. Romans believed, and continued to believe, that Germans were savages beyond the pale23. Caesar, because it suited his purpose, was happy to augment the myth by a pseudo-scientific ethnologia of his own.

What is more, he uses the formal German excursus to nurture seeds already sown earlier in the work. When we read the German ethnologia we have a sense of deja vu. Many of the

See Sherwin-White 1967:28f.

20

On skin clothing as the trademark of early primitive man see Lucr. 5.954f, 1011. Scyths were clad in skins (Cic. Tusc. 5.90; Verg. G. 3.383; Just. 2.2.9), as were the wild inhabitants of the Indian seacoast (Curt. 9.10.10). Fabulous Indian peoples are also said to wear skins (Mela 3.63; Pliny $H N$ 7.23), or to go about naked or barely clad (Mela 3.63).

21 1sid. Orig. 19.23.4: renones sunt velamina umerorum et pectoris usque ad umbilicum atque intoris villis adeo hispida ut imbrem respuant. 
details have been encountered before - in the digression on the Suebi in book 4. Being a German tribe, the Suebi show all the characteristics of their savage brethren - huge bodies, half-naked and clad in skins in the coldest weather ( $B$ Gall. 4.1.9-10), no private ownership of land and a nomadic existence ( $B$ Gall. 4.1.7), annual war raids ( $B$ Gall. 4.1.4-5), poverty and an (alleged) suspicion of foreign imports. (They are not even interested in baggage animals of quality, unlike the Gauls who have a passion for them and are prepared to pay exorbitant prices) ( $B$ Gall. 4.2.1-2,6). Desert vastnesses are their domain ( $B$ Gall. 4.3.1-2). The repetitions need not be explained in terms of Caesar's absentmindedness or a later interpolator. They may well be a deliberate attempt to reinforce the notion of Germans as uncivilized and unworthy of Roman benevolence.

Even the excursus on the Britons deserves a second look. The passage ( $B$ Gall. 5.12-14) reads like a functional reconnaissance report of the type one of Alexander's generals might have produced. Its tone is brisk and detached. Yet as with the Germanic excursuses, the arrangement of the traditional topoi and the details selected suggest an apologetic purpose. Britons are implicitly compared with Gauls and Germans, to the detriment of the latter, and to the greater glory of Caesar.

Caesar begins by mentioning the tribes near the coast with which he had dealings. They are identified with the civilized Gauls, are even said to be Belgic. They may live off milk and flesh, but (unlike Germans) they practise settled agriculture and live in homesteads fere Gallicis consimilia ( $B$ Gall. 5.12.3). Far from being indigent (like Germans), they have coinage and a thriving economy based on mining and timber - definitely worth exploring. Standard ethnographic topics like climate and the shape and location of the island follow, enlivened by a gentle reminder that Caesar has been there and conducted personal research ( $B$ Gall. 5.13.4). Then, significantly, the inhabitants of Kent, one of the maritime tribes mentioned earlier, are again given credit for being within the ambit of civilization, neque multum a Gallica differunt consuetudine ( $B$ Gall. 5.14.1) - deserving the attention of Caesar. Juxtaposed is a single sentence dismissing the tribes of the interior where Caesar never penetrated. They do not plant crops, they live off their flocks and are clad in skins no more worthy of conquest than remote nomadic Germans, in fact. The formidable appearance of Britons in general is then emphasized. Their smooth bodies painted with woad, with their long hair and moustaches, they would have presented a terrifying aspect to the Roman army. How much more impressive their capitulation. Caesar closes the excursus with a bland ethnographic topos, ties of kinship - to cover his traces perhaps?

Certainly in the light of the accounts of the Suebi and Germans, it is debatable whether Caesar selected these particular ethnographic details merely for their scientific interest.

Even before book 4 and the Suebi excursus, Caesar exploits Roman prejudices about Germans. In the course of the narrative, when his army is on the point of meeting Ariovistus's forces, we are given a graphic description of the panic in the Roman camp engendered by mere hearsay about the size and savagery of Germans (B Gall. 1.39.1). Ariovistus himself has just warned Caesar: intellecturum quid invicti Germani, exercitatissimi in armis, qui inter annos XIIII tectum non subissent, virtute possent. They apparently pose a considerable threat to Roman miltary might.

Ariovistus himself is presented as hopelessly intransigent, possessed of all the attributes of the classic barbarian: cruelty ( $B$ Gall. $1.31 .12,15 ; 32.4$ ), bad temper ( $B$ Gall 1.31 .13 ), recklessness ( $B$ Gall. 1.31.13), arrogance ( $B$ Gall. 1.31.12; 33.5; 44.8-13; 46.4)24 - a figure who deserved to be annihilated. 
Barbaric details designed to shock are also inserted into the narrative: superstition prevents the Germans from joining battle before the new moon. Like Scyths, women accompany their menfolk on campaign, the matres familiae actually reading the omens before battle ( $B$ Gall. 1.50.4-5). It was only right that such savages should be regarded as enemies of Rome as well as Gaul, and confined to the east bank of the Rhine.

Caesar's account of Ariovistus and the Germans may provide "a most remarkable example of the deliberate exploitation of national or racial prejudice" 25 , but this very exploitation diminishes its value as ethnography.

In assessing Caesar's ethnographic achievement Rawson states: "It might be fair to say that had he had no apologetic purposes he might have been one of the better authors of straightforward descriptions of remote peoples" (1985:263). This is a little severe. Caesar did introduce his own particular brand of personal observation into anthropological remarks in his narrative, for which he deserves ample credit. And in the traditional ethnologiae he made modest contributions to the development of the genre. It might be fairer to say that in spite of his apologetic purposes, Caesar is one of the better authors of straightforward descriptions of remote peoples.

\section{BIBLIOGRAPHY}

Balsdon, J.P.V.D. 1979. Romans and Aliens. London.

Beckmann, F. 1930. Geographie und Ethnographie in Caesars "Bellum Gallicum". Dortmund.

Capelle, W. 1929. Das alte Germanien. Die Nachtrichten der griechischen und romischen Schriftsteller. Jena.

Chadwick, N. 1971. The Celts. Harmondsworth: Pelican Books.

KJotz, A. 1910. Casarstudien. Leipzig.

Klotz, A. 1934. "Geographie und Ethnographie in Caesars Bellum Gallicum." Rheinisches Museum fur Philologie 66ff.

Macculloch, J.A. 1911. The religion of the ancient Celts. Edinburgh.

Momigliano, A. 1975. Alien Wisdom: The Limits of Hellenization. Cambridge: Cambridge University Press.

Müller, K.E. 1972. Geschichte der antiken Ethnographie und ethnologischen Theoriebildung. Von den Anfangen bis auf die byzantinischen Historiographen 1. Wiesbaden: Franz Steiner Verlag GMBH.

Müller, K.E. 1980. Geschichte der antiken Ethnographie und ethnologischen Theoriebildung. Von den Anfangen bis auf die byzantinischen Historiographen 2. Wiesbaden: Franz Steiner Verlag GMBH.

Norden, E. 1922. Die Germanische Urgeschichse in Tacitus Germania. 2nd edition. Berlin. 
Rawson, E. 1985. Intellectual Life in the Late Roman Republic. London:Duckworth.

Rice Holmes, T. 1907. Ancient Britain and the Invasions of Julius Caesar. Oxford: Clarendon Press.

Schroeder, A. 1921. De Ethnographiae Antiquae Locis Quibusdam Communibus Observationes. Halle. Dissertation.

Sherwin-White, A.N. 1967. Racial Prejudice in Imperial Rome. Cambridge: Cambridge University Press.

Strasburger, H. 1965. "Poseidonius on Problems of the Roman Empire." Journal of Roman Studies 55, 40-53.

Trüdinger, K. 1918. Studien zum Geschichte der griechisch-romischen Ethnographie. Basel. Dissertation.

Walser, G. 1956. Caesar und die Germanen. Studien zur politischen Tendenz romischer Feldzugberichte. Wiesbaden. 